Special Section: The economies, ecologies and politics of social forestry in Indonesia Research Article

\title{
Making the case for institutional support on designing agroforestry technology models for rehabilitating critical lands
}

\author{
Andi Nuddin ${ }^{1 *}$, Muhammad Arsyad ${ }^{2}$, Muhammad Ikbal Putera ${ }^{1}$, Nuringsih Nuringsih ${ }^{3}$, Temesgen \\ Tilahun Teshome ${ }^{4}$ \\ ${ }^{1}$ Faculty of Agriculture, Muhammadiyah University of Parepare, Indonesia; andinuddin1956@gmail.com \\ 2 Faculty of Agriculture, Hasanuddin University, Indonesia \\ ${ }^{3}$ Faculty of Economic, Muhammadiyah University of Parepare, Indonesia \\ ${ }^{4}$ College of Development Studies, Addis Ababa University, Ethiopia \\ * Corresponding author
}

\begin{abstract}
Land and forest management practices in developing countries have resulted in millions of hectares of degraded lands. This is caused by policy implementation unable to synergize between conservation-ecological goals, and the economic needs of farmer households. This study aims to showcase a model for bringing together economic and ecological interests more closely in line with one another. Furthermore, the study also presents an institutional structure of a program that could help to establish agroforestry-based land rehabilitation policies. The research employed includes a combination of Farming Income Analysis and Interpretative Structural Modeling Analysis. The results show that farming income, when employing agroforestry technology is higher than non-agroforestry approaches. Furthermore, agroforestry technology supports critical land rehabilitation and provides conditions for longer term sustainability. Therefore, a programmatic institutional approach is needed to support these dual goals. We identify that a programmatic approach would include: (1) applying conditions of an agroforestry system as a holistic structured unit, (2) improvement of farmer knowledge and skills, (3) increasing the role and capacity of relevant institutions, (4) improving coordination between sectors, (5) developing conservation agriculture systems, (6) improving bureaucratic support systems, and (7) strengthening control and supervision functions. These elements imply that implementation of agroforestry technology requires institutional support in designing policy for critical land rehabilitation, of which would have significant economic and ecological outcomes on critical lands.
\end{abstract}

Keywords: Agroforestry; governance institutions; Interpretative Structural Modeling; monoculture; critical lands

\section{Introduction}

Forest management practices, particularly in extractive natural resource economies in developing countries, have created conditions whereby millions of hectares of land remain degraded and underutilized. Therefore, the outcomes result not only in conservation and ecological challenges, but also in the form of limited economic opportunity for local farmers in the long term. Knowledge management is critical for identifying potential innovations for these dual challenges, such as supporting farmer innovation practices to increase production volume and quality (Duangta, Borisutdhi, \& Simaraks, 2018) and supported by adequate extension services (Gedgaew, Simaraks, \& Rambo, 2018). This paper identifies a case study for engaging on the dual goals of conservation and economic improvement on critical lands in Sulawesi, particularly in degraded watershed areas that have become the source of flash floods in recent years. If continued excessive management and exploitation of these lands persist, so will the expansion of critical land/forest areas that are in poor conditions. Among the critical nutrient-poor lands, several are characterized by steep slopes. These topographic conditions require careful management so as not to deviate from the principles of soil and water conservation. Nevertheless, the reality throughout the upper watershed indicates 
that there are still significant land exploitation practices taking place that exacerbate conditions of critical lands. Worse still, because the condition of the land is poor in nutrients, farmers that cultivate these lands also experience conditions of low productivity, keeping rural populations poor. Therefore, these overall symptoms indicate that there is an intertwined vicious cycle that is reinforced by land conversion and farmer income interests.

Land management in rough topographical conditions like those in the upper watersheds of Sulawesi therefore require an appropriate agrotechnology that can reduce surface flow and ensure the reduction of erosion potential. One approach that we have considered is a model of agroforestry technology, which is appropriate for contexts of land rehabilitation. Agroforestry technology includes business activities that can integrate agricultural, forestry and ecological development activities. As stated by Rahu, et al. (2015) in the case of a Dayak community in Central Kalimantan, agroforestry not only contributes to the preservation of the balance of forest ecosystems, but also supports socio-economic interests and cultural aspects. The Dayak community is an ethnic group from Central Kalimantan, which have similar inland cultivation approaches as the Bugis people of South Sulawesi. They also both practice land cultivation systems by applying agroforestry technology systems. Therefore, based on an economic perspective, the application of agroforestry systems can help to integrate various types of plants in one area to meet economic interests and welfare concerns of farmers (Cordeiro, et al., 2018). However, for various reasons there are many cases that show farmers switching from agroforestry to "conventional" systems, which are indicative of single-crop agriculture. This raises new problems in relation to land rehabilitation and soil conservation, which also disrupt and affect local economic systems.

The failure of land rehabilitation and soil conservation is caused by various factors, including: (1) the weakness and/or inaccuracy of the technology applied, (2) limited funding, and/or (3) institutions that do not play an optimal role (Nuddin et al., 2007). All three interact with, and affect one another, so that even though the technology that is applied may be fairly precise, it can still fail to achieve its objectives. This is foremost due to lack of institutional support. Furthermore, a land and forest management technology will unlikely be adopted by farmers if there is weak coordination by the institutional structures designed to support local farmers in land rehabilitation.

Agroforestry technology adheres to a multi-cropping system with a variety of plants, from seasonal crops (foodstuffs) to long-term perennials. This cropping pattern produces a layered canopy structure that is able to reduce the kinetic energy of raindrops, and reduce erosion. Therefore, the agroforestry system carries two main functions, namely: (1) production/economic functions, and (2) conservation/ecological functions (Hakim, et al., 2018). In terms of production, farming of agroforestry systems is a source of production of food, animal feed, building materials (wood), rubber, and medicines. Whereas from a conservation point of view, the role of agroforestry includes erosion prevention, control of soil fertility, preservation of water systems, and protection of biodiversity (Moreno, et al., 2018).

Therefore, the purpose of this study is twofold. First, we describe farming technologies that are more economically and ecologically advantageous for the given study locations related to critical lands in the upper watersheds of sites in Sulawesi. In particular, we compare agroforestry models with non-agroforestry/monoculture models. Second, through an interpretive structural modeling analysis, we show whether institutional support is needed in designing policies for the application of agroforestry technology to rehabilitate critical land. In order to determine a model farming technology (agroforestry and non-agroforestry/monoculture) that is more economically profitable, an income analysis is carried out. Meanwhile, to measure the importance of institutional support in designing policies for implementing agroforestry technology in rehabilitating critical land, an Interpretative Structural Modeling (ISM) analysis was carried out. 


\section{Materials and method}

\subsection{Research site}

The research was done in the Bila Watershed in South Sulawesi, Indonesia (Figure 1). The watershed covers three jurisdictional districts, namely Enrekang, Sidenreng Rappang, and Wajo. The location of the research was conducted on dry lands marked as farming land. If it is generally a landscape with a critical gradient, it has an impact on the magnitude of the fluctuations in the river flow between two different seasons (rainy and dry seasons).

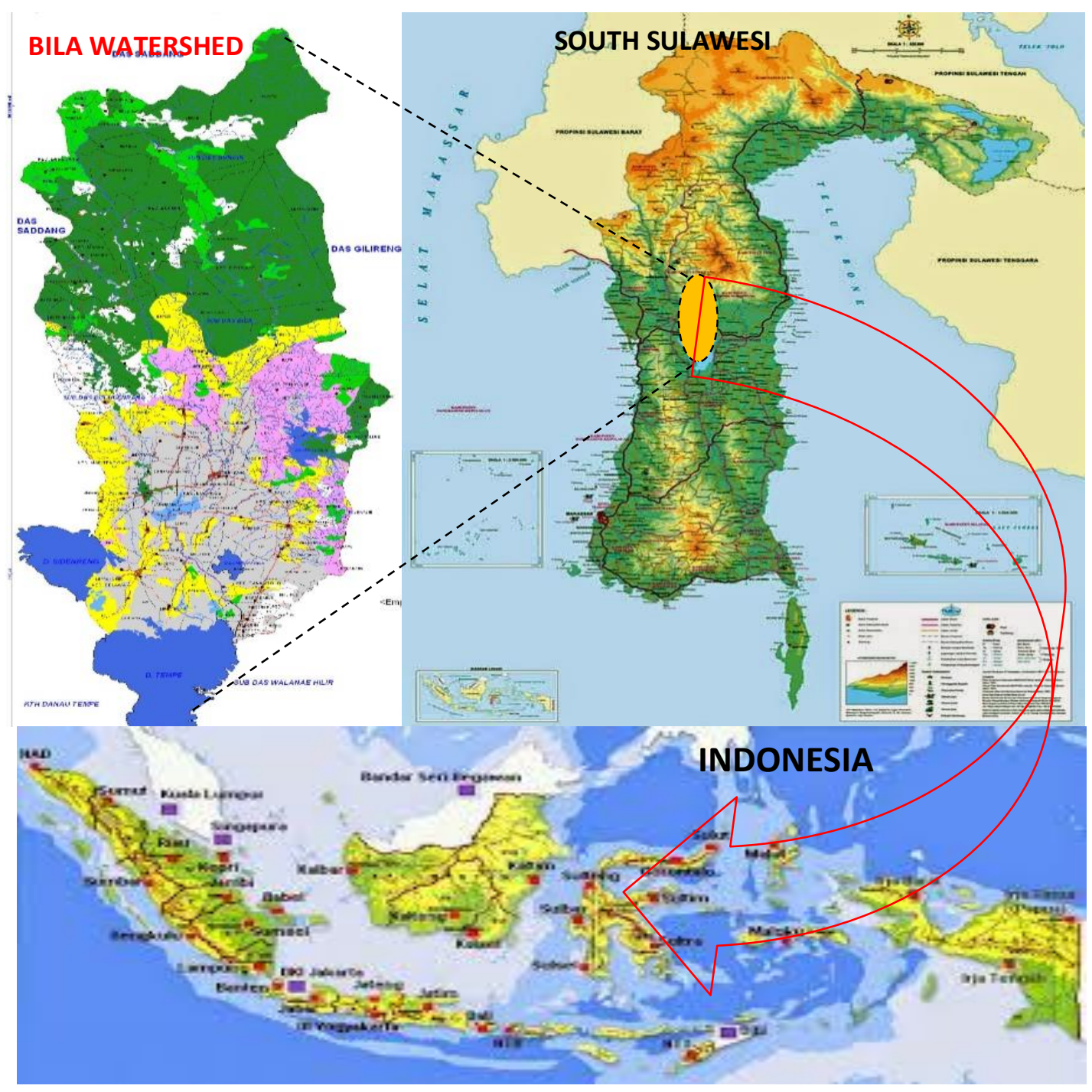

Figure 1. Watershed area as a research location

\subsection{Research Design and Analysis}

For this study, we selected 24 dryland farmers for each of the two categories. One group consisted of farmers applying agroforestry and the other non-agroforestry/monoculture technology. The location of this study consisted of two groups of very different biophysical characteristics, namely the biophysical structure of agroforestry plots and those with nonagroforestry/monoculture cultivation. This study was conducted in a descriptive manner with survey methods designed using two analytical methods as shown in Table 1. 
The first methodological approach includes an income analysis to determine differences in farm income that applies for agroforestry and non-agroforestry systems. Second, the Interpretative Structural Modeling (ISM) method measured how much institutional support is present for determining critical land management policies (Didu, 2001). The ISM method begins with the determination of sub-elements (variables), which were identified through group discussions with a number of experts/practitioners; 13 sub-elements are alternative variables for determining priority land management programs. These alternative variables were chosen for consideration as a variable that can be implemented in critical land program if supported by institutions related to critical land management.

\subsubsection{Farm income analysis}

Farm income analysis was employed to develop an overall understanding of farmer income differentiation between those who apply agroforestry and non-agroforestry technology models. The following equations were applied:

$P=T R-T C$

Where:

$P=$ Income

$T R=$ Total agroforestry/non-agroforestry model farm revenue

$=$ Total product $\mathrm{x}$ price

$\mathrm{TC}=$ Total expenditure $=$ Fixed costs + Variable costs.

Table 1. Study design of the agroforestry technology model

\begin{tabular}{|c|c|c|c|c|}
\hline Problem & Object & Analysis & $\begin{array}{l}\text { Technological model applied by } \\
\text { farmers }\end{array}$ & $\begin{array}{l}\text { Data collection } \\
\text { technique }\end{array}$ \\
\hline $\begin{array}{l}\text { 1. Problems with } \\
\text { management } \\
\text { \& utilization of } \\
\text { critical land } \\
\text { 2. Farmer } \\
\text { activities to } \\
\text { increase } \\
\text { income. }\end{array}$ & $\begin{array}{l}\text { 1. Showing the most } \\
\text { appropriate model } \\
\text { can increase farmer } \\
\text { income } \\
\text { 2. Estimating and } \\
\text { calculating the } \\
\text { contribution of } \\
\text { farming income }\end{array}$ & $\begin{array}{l}\text { Technology } \\
\text { based on } \\
\text { local } \\
\text { knowledge to } \\
\text { improve land } \\
\text { conditions, so } \\
\text { that farmer } \\
\text { income } \\
\text { increases }\end{array}$ & $\begin{array}{l}\text { Agroforestry technology model: } \\
\text { 1. Model I: Combination of Pine } \\
\text { Merkusii + Arabica Coffee + } \\
\text { Cloves + Corn } \\
\text { 2. Model II: Combination of Pine } \\
\text { Merkusii + Arabica Coffee + } \\
\text { Soybeans } \\
\text { 3. Model III: Combination of Pine } \\
\text { Merkusii + Coffee + Cloves + } \\
\text { Soybeans } \\
\text { Non-agroforestry model } \\
\text { 4. Model IV: Shallot monoculture } \\
\text { system } \\
\text { 5. Model V: Vegetable } \\
\text { monoculture system } \\
\text { 6. Model V: Corn monoculture } \\
\text { system }\end{array}$ & $\begin{array}{l}\text { Observation, } \\
\text { field and } \\
\text { interview with } \\
\text { farmers. }\end{array}$ \\
\hline $\begin{array}{l}\text { 3. The importance } \\
\text { of agroforestry } \\
\text { technology as } \\
\text { a priority } \\
\text { program in } \\
\text { forest / land } \\
\text { rehabilitation } \\
\text { institutions }\end{array}$ & $\begin{array}{l}\text { 3. Demonstrate the } \\
\text { position of } \\
\text { agroforestry } \\
\text { technology as a } \\
\text { priority program in } \\
\text { institutional } \\
\text { rehabilitation of } \\
\text { forests / land }\end{array}$ & $\begin{array}{l}\text { Interpretative } \\
\text { Structural } \\
\text { Modeling }\end{array}$ & $\begin{array}{l}\text { Structural level and synergy of } \\
\text { agroforestry technology with } \\
\text { other programs in forest / land } \\
\text { rehabilitation institutions }\end{array}$ & $\begin{array}{l}\text { Observation, } \\
\text { field interviews } \\
\text { and interviews } \\
\text { with } \\
\text { stakeholders }\end{array}$ \\
\hline
\end{tabular}




\subsubsection{Interpretative structural modeling}

To design the structure and position model of the agroforestry technology model in the forest /land rehabilitation institution, Interpretative Structural Modeling (ISM) analysis was carried out. ISM is an assessment conducted by identifying groups to produce structural models of systems designed through images and sentences (Saxena 1999 and Didu., 2001). Fundamental reasons for using this tool is that ISM can prove the importance of institutions related to critical land management. The number of experts / practitioners in the required sample are not large (20 people), which were determined on a purposively based method to develop a level of understanding and/or relevance of their respective fields of work in the rehabilitation of critical lands. Data obtained in the field was obtained as a result of comparisons across the 13 sub-elements, which were analyzed through stages so as to produce a model of the interconnection structures of sub elements. Data obtained in the field were analyzed by developing a structural Self-Interaction Matrix (SSIM) using the results of the questionnaire tabulation; compiling the reachability matrix table by replacing the symbols $\mathrm{V}, \mathrm{A}, \mathrm{X}, \mathrm{O}$ with numbers 1 and 0 ; compiling the Power-Dependent Matrix Driver (DP-D) consisting of four quadrants; and, developing a structural model (level) for each element.

\section{Results and discussion}

\subsection{Technology model of critical land farming}

This description compares two farming system models, which are described as distinct farming technologies, namely agroforestry and non-agroforestry/monoculture models. The agroforestry model is a form of intercropping farming that combines forestry and agricultural crops, such as a combination of forestry crops such as pine bran, plantation crops (coffee, cacao, and/or clove). Sometimes in certain seasons, plantation crops are interspersed with food crops (corn, cassava and/or soybeans). Furthermore, farming that has not applied agroforestry/monoculture technology include plots that cultivate corn, shallots, and/or other types of vegetables. The results of the field research show that the realization of the two farming technology models applied by farmers can further be broken down into several farming sub-models as presented in Table 2.

Table 2. The technology/farming system model applied by farmers

\begin{tabular}{|c|c|c|}
\hline $\begin{array}{c}\text { Farming } \\
\text { Technology Model }\end{array}$ & Sub Model & Plant type \\
\hline Agroforestry & $\begin{array}{l}\text { I } \\
\text { II } \\
\text { III }\end{array}$ & $\begin{array}{l}\text { Pinus merkusii + Arabica + Clove }+ \text { Corn } \\
\text { Pinus merkusii }+ \text { Arabica coffee }+ \text { Soybeans } \\
\text { Pinus merkusii }+ \text { Clove }+ \text { Arabica Coffee }+ \text { Soybeans }\end{array}$ \\
\hline $\begin{array}{l}\text { Non-agroforestry/ } \\
\text { monoculture }\end{array}$ & $\begin{array}{l}\text { IV } \\
\text { V } \\
\text { VI }\end{array}$ & $\begin{array}{l}\text { Red onion } \\
\text { Cabbage } \\
\text { Corn }\end{array}$ \\
\hline
\end{tabular}

Source: field research

Both of these farming technology models are applied to critical categories of land uses with slope classes ranging from mild, moderate to steep.

\subsection{Ecological impacts of applying the agroforestry technology model}

The agroforestry technology model implemented by farmers (sub-models I, II, and III) 
presented in Table 2 provides many ecological and environmental benefits. This is a result of differences in farming management in the two models as shown in Table 3.

Table 3. Differences in farming management according to the technology model

\begin{tabular}{|c|c|c|c|c|}
\hline \multirow{2}{*}{$\begin{array}{l}\text { Technology } \\
\text { Model / } \\
\text { farming } \\
\text { system }\end{array}$} & \multicolumn{4}{|c|}{ Farming Management } \\
\hline & Land processing & $\begin{array}{l}\text { Use of fertilizers } \\
\text { (Urea, NPK, Phonska, } \\
\text { and ZA) }\end{array}$ & $\begin{array}{l}\text { Use of Pesticides } \\
\text { (Insecticides, Fungicides, } \\
\text { and Herbicides) }\end{array}$ & Use of labor \\
\hline Agroforestry & Not intensive & $\begin{array}{l}\text { Only at the beginning of } \\
\text { the planting season }\end{array}$ & Light & Low \\
\hline $\begin{array}{l}\text { Non- } \\
\text { agroforestry/ } \\
\text { monoculture }\end{array}$ & Intensive & $\begin{array}{l}\text { At the beginning, middle } \\
\text { and end of the crop } \\
\text { cultivation cycle }\end{array}$ & $\begin{array}{l}\text { Without pesticides, } \\
\text { production is not optimal }\end{array}$ & High \\
\hline
\end{tabular}

Source: field research

Differences in the application of agroforestry and non-agroforestry/monoculture technology models have a significant impact on ecological systems. First, agroforestry technology enables the creation of multi-strata canopy. Long-term perennials in the form of dominant trees occupy the topmost canopy, while food crops occupy the lowest strata. Such canopy structures have a positive effect on soil protection as part of interactions with rainfall. Likewise, the presence of leaves and twigs form a layer of litter that can increase water infiltration and reduce surface runoff. Increased infiltration and decreased surface flow have a further impact on erosion. Therefore, agroforestry technology strongly supports soil and water conservation efforts.

Second, non-intensive agroforestry land management will maintain the stability of the drainage system and maintain soil permeability so as to ensure the suitability of the soil structure. This factor is extremely important for plant growth. In addition to litterfall that covers the land surface in the agroforestry farming system, it can also help guarantee the balance of the content of organic elements needed by plants. Tongkaemkaew et al. (2018) also found that the application of rubberbased agroforestry technology increased litter volume so that the carbon cycle and nutrients were maintained at optimal levels, which resulted in a decrease of fertilizer used by farmers. In contrast, non-agroforestry/monoculture land management is very intensive. The land is always stretched to its maximum production capacity, and this is especially true at the beginning of the planting season. Such factors can increase surface erosion. Therefore, the level of land washing is very high, which depletes nutrient content.

Third, the agroforestry technology model is also able to minimize the use of fertilizers (urea, NPK, Phonska, and ZA). Table 3 shows the difference in fertilizer requirements, whereby the application of fertilizer to the agroforestry technology is carried out only at the beginning of planting. On the other hand, in the non-agroforestry/monoculture model, fertilizer application is carried out throughout the planting period. As farmers explained "my experience as a farmer using agroforestry technology has never used fertilizers, except for organic fertilizer that I obtained from litter. Therefore, the costs that I use in farming are very small because I do not use chemical fertilizers". Thus, there are differences in land characteristics between the two models but also other factors and dependencies at play. The land conditions in the agroforestry technology model are maintained without putting heavy pressure on the land, as a result of farmers not clearing all forest plants, and also affects the production costs. In contrast, the most intensive nonagroforestry/monoculture land processing system is onion farming. Land management is very intensive in this cultivation system, requiring first the clearing of forest plants resulting in the greater likelihood for erosion, soil washing, and loss of nutrients. This kind of tillage condition has an impact on the high use of fertilizers every planting season. 
Fourth, farming in the agroforestry technology model does not require much use of pesticides, if any. In contrast there is a much larger dependency for pesticides in the monoculture farming systems as shown in Table 3. Because the need for pesticides in agroforestry technology models is low, maximizing production is not determined by pesticide use. This is very different from the monoculture farming system, where maximizing production is conducted through the use of pesticides, which sometimes exceed tolerated limits.

Fifth, the agroforestry technology model can also minimize the use of labor when compared to monoculture farming. The low number of workers needed is inseparable from: (1) land management that is not intensive, (2) fertilization carried out only at the beginning of planting, and (3) use of pesticides that are not continuous. This is the opposite of the labor requirements in the monoculture farming system, which includes: (1) intensive land management, (2) fertilization carried out continuously throughout cultivation from the beginning, middle, and end of the planting, and (3) continuous use of pesticides to maximize production.

\subsection{Economic Impacts of the Application of the Agroforestry Technology Model}

In general, farming financing can be divided into two parts, namely: fixed costs, which are costs incurred by farming that are not directly related to total production; and non-fixed costs, which incur a number of expenses for farming needs which directly affect production. Based on the results of observations and interviews with respondents in the field and subsequent calculation of production costs based on market price standards, we show a significant difference between the use of farming costs for agroforestry and non-agroforestry/monoculture technology models. The details are provided in Table 4, shown as differences in production costs, beginning with the fixed costs (purchase, equipment, depreciation of equipment), up to the variable costs (seeds, fertilizers, pesticides, and labor) as in Table 4.

Table 4. Differences in production costs based on farming technology model

\begin{tabular}{llrr}
\hline & & \multicolumn{2}{c}{ Production cost } \\
\cline { 2 - 4 } Cost Type & Description & $\begin{array}{r}\text { Agroforestry } \\
\text { (IDR/ha/year) }\end{array}$ & $\begin{array}{c}\text { Non-agroforestry/ } \\
\text { monoculture (IDR/ha/year) }\end{array}$ \\
\hline Fixed cost: & Equipment Purchases & $805,000,00$ & $1,282,000,00$ \\
& Land tax & $15,000.00$ & $15,000,00$ \\
& Depreciation & $\underline{22,500.00}$ & $\underline{38,055.00}$ \\
& Seed & $842,500.00$ & $1,729,388.00$ \\
Variable cost: & $1,166,667.00$ & $2,708,333.00$ \\
& Fertilizer: & & \\
& Urea & $265,26.00$ & $708,400.00$ \\
& NPK & $2,163,151.00$ & $2,397,005.00$ \\
& Phonska & $320,000.00$ & $426,667.00$ \\
& ZA & $208,542.00$ & $137,500.00$ \\
& Pesticides: & $181,133.00$ & $3,325,000.00$ \\
& Insecticide & $480,000.00$ & $2,913,000.00$ \\
& Fungicide & $76,125.00$ & $241,500.00$ \\
& Herbicide & $\underline{455,000.00}$ & $\underline{1,165,000.00}$ \\
& Labor & $4,926,315.00$ & $10,083,361,00$ \\
\hline & Total & $5,752,027.00$ & $12,803,759.00$ \\
\hline
\end{tabular}

Source: calculated by authors 
Differences in production costs are indicated as fixed costs (purchases, equipment, depreciation of equipment), to variable costs (seeds, fertilizers, pesticides, and labor). The application of the non-agroforestry/monoculture technology model uses the cost of purchasing smaller equipment (IDR 805,000/ha) compared to non-agroforestry technology (IDR 1,282,000/ha). This difference is caused by the farming of agroforestry technology models that do not use much production equipment.

The use of water machines in monoculture farming (shallots, cauliflower, and corn) is required, while in the application of agroforestry technology models, such equipment is not needed. Plants on agroforestry farms have sufficient water supply, both from rainwater and moisture by microclimate effects. Furthermore, the root system and litter layer on the floor of the land helps to retain rainwater. All of this is possible due to the interaction between forestry plants and agricultural crops (agroforestry). Furthermore, the cost of procurement of seeds also presented an additional difference. Specifically, in the application of the agroforestry technology model expenditures reached IDR 1,166,667/ha, while the non-agroforestry/monoculture technology model was up to IDR 2,708,333/ha. The low cost of procuring seedlings in agroforestry farming is an indication of the need for seeds in agroforestry farming activities, almost all of which can be prepared or can be seeded by each farmer. In addition, there are differences in the cost of pesticides between agroforestry technology models with the total cost of pesticides used reaching IDR 737,258/ha, while non-agroforestry/monoculture farming (shallots, cabbage and corn) amounted to a cost of procurement of costly pesticides at IDR 6,479,500 / ha.

Varied production inputs not only caused differences in total production costs, but also differences in labor costs between farming agroforestry and non-agroforestry/monoculture technology models, as shown in Table 4. Labor costs of non-agroforestry/monoculture farming are almost three times greater (IDR 1,165,000/ha) compared to agroforestry technology farming (IDR $455,000 /$ ha). Thus, the total cost of production of non-agroforestry/monoculture farming is very large (IDR $12,803,759 /$ ha), which is twice the total production cost of agroforestry technology (IDR $5,752,027 /$ ha).

Table 5. Total farmer income based on farming technology model/sub model

\begin{tabular}{|c|c|c|c|}
\hline Technology Model & Sub model & Combined / cultivated plants & $\begin{array}{c}\text { Revenue } \\
\text { (IDR/ha/year) }\end{array}$ \\
\hline \multirow{4}{*}{ Agroforestry } & 1 & Pinus merkusii + Arabica + Clove + Corn & $15,364,621$ \\
\hline & II & Pinus merkusii + Arabica coffee + Soybeans & $2,337,138$ \\
\hline & III & $\begin{array}{l}\text { Pinus merkusii + Clove + Arabica coffee + } \\
\text { Soybeans }\end{array}$ & $18,535,542$ \\
\hline & & & $36,237,301$ \\
\hline \multirow{4}{*}{$\begin{array}{l}\text { Non } \\
\text { agroforestry }\end{array}$} & IV & Red onion & $15,313,649$ \\
\hline & $\mathrm{V}$ & Cabbage & $4,015,338$ \\
\hline & $\mathrm{VI}$ & Corn & $3,611,354$ \\
\hline & & & $22,940,541$ \\
\hline
\end{tabular}

Source: calculated by authors

From an economic perspective, land use for farming by applying agroforestry technology models is more profitable compared to non-agroforestry/monoculture farming. This is due to the combination of forestry plants and agricultural crops that can produce various types of commodities, with higher economic value. For example, Pinus merkusii forestry plants can produce 
pine resin, in addition to agricultural crops that produce commodities such as arabica coffee, cloves, corn, and soybeans. Table 5 shows the differences in revenue of farmers according to combinations of cultivated crops (Table 5).

Table 5 clearly shows that the average revenue for farmers that have applied the agroforestry technology model is greater than that of farmers who apply the non-agroforestry/ monoculture technology model. Farmer selection to apply the agroforestry technology model is determined by commodity variations produced by the three sub-models of agroforestry technology, namely four commodities in sub-model I, three commodities in sub-model II, and four commodities in sub-model III. The remaining sub-models in the non-agroforestry/monoculture technology model also consists of three types with each producing one commodity, namely shallots in sub-model IV, cabbage in sub-model V, and corn in sub-model VI.

The amount of production costs affects the level of income obtained by farmers. There are differences in the income of farmers who apply the agroforestry technology model with farmers applying the non-agroforestry technology model as shown in Table 6. Farmers who apply the agroforestry model earn four times more income than farmers who apply the nonagroforestry/monoculture model. Thus, the application of agroforestry technology farming models is more economically profitable, compared to non-agroforestry/monoculture farming. This is similar to the findings of Jalon, et.al. (2018), that show the agroforestry model can increase community welfare to levels higher than non-agroforestry/monoculture systems.

Table 6. Farmer income by technology model applied

\begin{tabular}{lccc}
\hline \multicolumn{1}{c}{ Technology model } & $\begin{array}{c}\text { Benefit } \\
\text { (IDR/ha/year) }\end{array}$ & $\begin{array}{c}\text { Total Cost } \\
\text { (IDR/ha/year) }\end{array}$ & $\begin{array}{c}\text { Revenue } \\
\text { (IDR/ha/year) }\end{array}$ \\
\hline Agroforestry & $36,237,301$ & $5,752,027$ & $30,485,274$ \\
Non-agroforestry/monoculture & $22,940,541$ & $12,803,759$ & $7,646,822$ \\
\hline
\end{tabular}

Source: calculated by authors

\subsubsection{The agroforestry technology model in critical land management}

Based on the results of the analysis, both ecologically and economically, agroforestry technology is a viable alternative and substitution to be applied to improve the management of critical land. This technology can synergize agricultural production, forestry and improve land quality (Alao, J.S., \& R.B. Shuaibu. 2013). However, further analysis is still needed, especially on how the strength of institutional support in implementing the agroforestry technology model as a strategic program in forest and land rehabilitation. Without such pre-requisites a transition to agroforestry to improve critical lands are unlikely.

In the study of watershed critical land management institutions, the results of the Interpretative Structural Modeling (ISM) analysis show that of the 13 sub-elements, nine of them are priority programs, while four are in the independent position, and five are in the linkage position. These are schematically listed in Table 7 . One of the programs recommended immediate implementation of the agroforestry technology model. This position (linkage) indicates that agroforestry technology is a program with a large contribution to the successful management of critical land ( $D P=0.62)$, but dependence on other sub-elements is also large $(D=0.69)$.

The continuity of the agroforestry technology program relies heavily on how government policies, including the support of the Ministry of Agriculture and Rural Development (Hoang. et al., 2017), and other programs, such as support from the Conservation Agriculture System (SPK) development program (DP $=0.77)$. The application of the SPK in the concept of critical land management is synonymous with the agroforestry technology model. In addition, the agroforestry 
technology program also depends on field extension program effectiveness (each DP $=0.92$ ) and the program to increase knowledge and skills among administrators (DP $=0.62$ ).

In addition to the programs stated above, the adoption of agroforestry technology also relies heavily on fellow programs in the linkage position. One of them is the enormous dependence on programs to improve farmer knowledge and skills. In this analysis, increasing farmer knowledge and skills ( $D P=1.00$ ) is also the same as Hoang et al.'s findings (2017). They also show that it is a key priority program in the management of critical land. The results of this study are relevant to the findings of Duangta et al. (2018) that for the sake of sustainability, the involvement of local communities is very important in supporting agroforestry. The role of local communities is not just physical participation, but must also be motivated through education and training, economic incentives to transition to multi-cropping systems, knowledge about the timing of increased productivity of agroforestry, and potential additional incentives emergent through the development of ecotourism and agro-tourism.

Table 7. Position and weight of priority programs in the management of critical watersheds

\begin{tabular}{|c|c|c|c|}
\hline \multirow{2}{*}{ Position } & \multirow[t]{2}{*}{ Activity / Activity Program } & \multicolumn{2}{|c|}{ score } \\
\hline & & $D P$ & $D$ \\
\hline Independent & 1. Development of a conservation farming & & \\
\hline (Influence on the program & system & 0.77 & 0.38 \\
\hline is strong, but its & 2. Development of a social control function & 0.67 & 0.46 \\
\hline connection with other & 3. Effective field counseling & 0.92 & 0.54 \\
\hline \multirow[t]{2}{*}{ activities is weak). } & 4. Increased knowledge and skill apparatus & 0,62 & 0.54 \\
\hline & Average & 0.74 & 0.48 \\
\hline Linkage & 5. Increased knowledge and farmer's skills & 1.00 & 0.69 \\
\hline (Its influence on the program & 6. Effectiveness of the role of relevant & 0.92 & 0.69 \\
\hline is strong and the level of its & institutions & 0.85 & 0.69 \\
\hline association with other & 7. Providing incentives & 0.62 & 0.69 \\
\hline \multirow[t]{3}{*}{ activities is also strong). } & 8. Application of agroforestry technology & 0.85 & 0.69 \\
\hline & 9. Effective coordination between sectors & & \\
\hline & Average & 0.82 & 0.74 \\
\hline Dependent & 10. Application of conservation technology $*$ ) & 0.15 & 0,62 \\
\hline (Its influence on the & 11. Increased community participation *) & 0.38 & 0.62 \\
\hline program is weak but its & 12. Program socialization *) & 0.31 & 0.77 \\
\hline \multirow[t]{2}{*}{$\begin{array}{l}\text { connection with other } \\
\text { activities is strong). }\end{array}$} & $\begin{array}{l}\text { 13. Development of community cultural wisdom } \\
* \text { ) }\end{array}$ & 0.08 & 0.62 \\
\hline & Average & 0.23 & 1.66 \\
\hline
\end{tabular}

Note: ${ }^{*}$ ) Programs are not a priority

Source: Analyzed by authors

Furthermore, the application of the agroforestry technology model relies heavily on the effectiveness of the role of the relevant institutions ( $D P=0.92$ ) both government and private, as well as coordination effectiveness between sectors ( $D P=0.85$ ). In the context of developing critical land management programs, support is needed in the form of incentives, especially for farmers who have and apply skills that support the Conservation Agriculture System program and agroforestry technology models.

Synergy between programs as illustrated in Figure 2, indicates the importance of institutional support in the application of agroforestry technology models, as indicated by the weight of power program driver in the role of the relevant institutions ( $D P=0.92$ ) and effective coordination between 
sectors (DP $=0.85)$. Both of these programs are very important because conflicts often occur between institutions as a cause of weak coordination functions in institutional agricultural production (Nuddin, et al., 2015). This institutional support for the application of agroforestry technology is urgently needed because agroforestry technology is not an independent conservation action, but rather fits in as an integral part of the strategy for land rehabilitation and soil conservation (Murthy.et al., 2016). Figure 2 shows that the 13 sub-elements as a program in managing critical land are distributed in three quadrants, namely four in independent positions, and five in linkage positions. Independent quadrants show all the programs in them have a large influence on the success of management of critical land (average DP $=0.74$ ), in addition to dependence on other programs, which is small (average $D=0.48$ ). The linkage quadrant shows that the program, in addition to having a large influence on the success of managing critical land, also relies on other programs. Therefore, all programs in this quadrant must be managed more effectively, because their dependence on other programs can create new problems if they are not managed carefully.

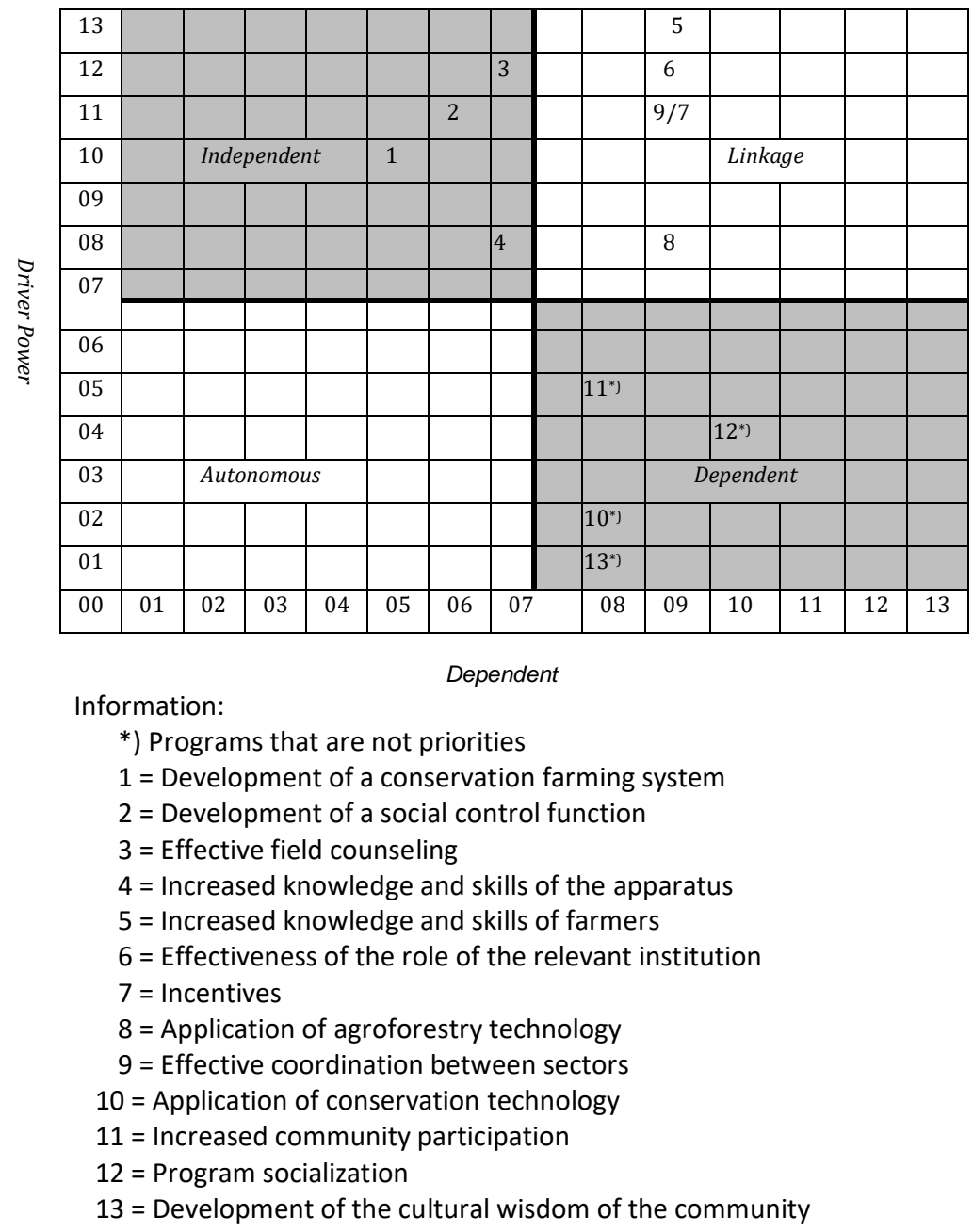

Figure 2. Power-dependence driver position and frequency as an indicator priority program in the management of Watershed critical land.

Furthermore, awareness is dependent, which means that loading programs is not a priority. Its influence on critical land management programs is very weak, in addition to its dependence on other large programs. Therefore, the programs in it can run on their own, if other programs are in an 
independent quadrant and the linkage runs optimally. Based on the description above (Figure 2), it can be stated that the structural model of program linkages in agroforestry-based critical land management institutions in watersheds (Figure 3).

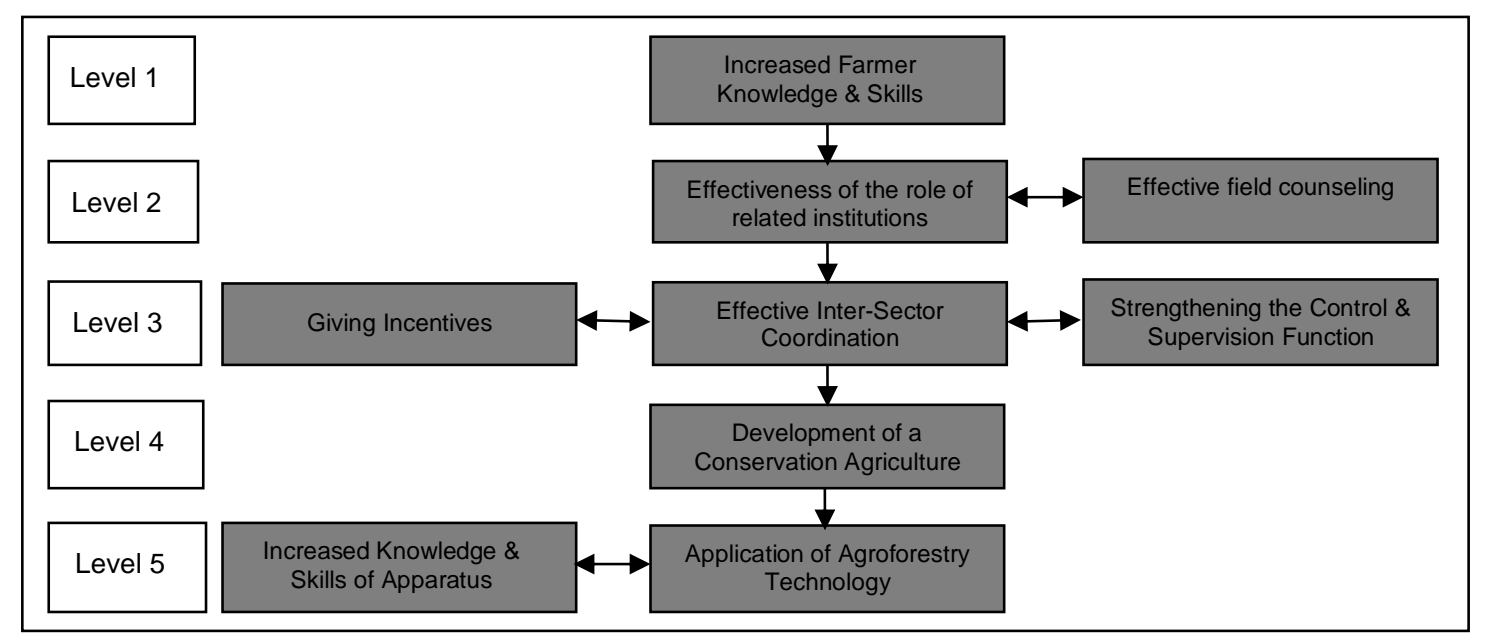

Figure 3. Program linkage structure model in agroforestry-based critical land management institutions.

Figure 3 shows that the increase in farmer knowledge and skills is a critical land management program at level 1 . This indicates that the program is a key element of success (DP $=1.00$ ) in managing critical lands. The importance of this program can be identified where farmers are the spearhead in the application of farming technology, including in terms of the application of agroforestry technology. The importance of increasing farmer knowledge has also been revealed by Nuddin et al. (2018), as one of the strategies in developing Robusta coffee through an agroforestry technology model in South Sulawesi.

At level 2 there is a priority program for the effectiveness of the roles of relevant institutions and the effectiveness of the role of extension agents. Related institutions include: Office of Agriculture, Forestry and Plantation, Field Extension Agency (Agriculture, Plantation, Forestry), Farmers' Groups. These institutions must collaborate together under one commitment so that the role of the field instructor is more effective in accordance with their duties and functions. At level 3 there are three strategic programs, namely: (1) effectiveness of coordination between sectors, (2) provision of incentives, and (3) strengthening of the control and supervision functions. Figure 3 shows that effective coordination between sectors is a program that is in a central position in strengthening critical land management institutions. This program will strengthen the functions of control / supervision and provide incentives for forest and critical land management. Control and supervision in forest and land management have been very weak so far, while the provision of incentives including payments for ecosystem services (Villamor et al., 2014) has not been implemented. One problem that has even become a national problem is that forest fires every dry season are never extinguished as a result of weak control and supervision. Control and supervision will be more effective if sectors coordinate better, and in turn, the role of related institutions will become more effective.

At level 4 there is only one development program for conservation agriculture systems (SPK). Through this system, a crop structure is created that guarantees the achievement of economic goals and the goal of conservation of natural resources and conservation of land and water. The conservation farming system is synonymous with agroforestry systems in which there is a 
combination of farming and agriculture approaches such as fruits, nuts, bananas, and several other products that can be sold in markets (Mercer et al., 2014). Therefore, SPK can help to realize agroforestry patterns as a buffer against protected areas and cultivation areas (Asase \& D.A. Tetteh. 2010). In level 5 , there is a program to implement agroforestry technology and a program to increase the knowledge and skills of the supporting agencies. Appropriate knowledge and skills will be improved if the role of relevant institutions can be made effective. This has been revealed by Knapp, and Sadorsky, (2010), especially in terms of developing marketing programs and increasing overall knowledge of officials. The implementation of agroforestry will be more efficient, therefore, if it is supported by the institutional structure of forest and land management programs, especially the relevant institutional effectiveness programs, and the effectiveness of coordination between sectors.

Even so, until now institutional support has not been in line with expectations. The facts in the field show that in terms of quantity, the number of farmers who switch from agroforestry systems to monoculture is still high. This is true even though it is widely accepted that an agroforestry system is strategic both from an environmental and economic point of view. This finding is similar to that revealed by Camilli et al. (2018) that although agroforestry is very positive in terms of production and environment, if it has not been supported by a good management structure, it will not come to fruition. Therefore, capacity building for institutions is an effective strategy to promote the development of agroforestry.

\section{Conclusion}

This paper has provided a strong case for agroforestry in the rehabilitation of degraded lands both economically and ecologically. Some principal findings are: (1) farming income with agroforestry technology is higher than non-agroforestry (or the economic purpose), (2) to enhance benefits and sustainability of agroforestry technology in critical land rehabilitation, an institutional and programmatic approach is required. These include: (1) the application of an agroforestry system that is a holistic and structured unit, (2) improvement of farmer knowledge and skills, (3) enhancement of the role of relevant institutions, (4) effective coordination between sectors, (5) development of conservation agriculture systems (the ecological purpose), (6) improvement in government institutions knowledge and skills, and (7) strengthening control and supervision functions. The presence of leaves and twigs on the surface of the land managed through agroforestry technology, produces litter layers which function to increase water infiltration /minimize surface runoff, and which neutralize the organic material needed by plants. In addition, the need for fertilizer and pesticide use in agroforestry systems tends to be relatively small, or as the case study sites have shown amount to half of the needs for fertilizer and pesticides for nonagroforestry /monoculture farming. Therefore, farming that applies the agroforestry technology model is an environmentally friendly farming technology that is able to neutralize and better maintain ecosystem balance avoiding degradation and encouraging restoration. These facts imply that implementation of agroforestry technology really needs institutional support in designing policy for critical land rehabilitation.

\section{Conflicts of Interest}

The authors declare that we have no conflict of interest.

\section{Acknowledgments}

The authors would like to thank the Provincial Government of South Sulawesi for their recommendation to do this research. Special thanks also goes to the Watershed Office of South Sulawesi for providing all data that enabled us to conduct the initial mapping of all stakeholders (especially experts) and for their valuable participation during discussions that supported earlier formulations of this paper. 


\section{References}

Alao, J.S., \& R.B. Shuaibu. (2013). Agroforestry Practices and Concepts in Sustainable Land Use Systems in Nigeria. Journal of Horticulture and Forestry. 5(10): 156-159. doi: https://doi.org/10.5897/JHF11.055

Asase, A., \& D.A. Tetteh. (2010). The Role of Complex Agroforestry systems in the Conservation of Forest Tree Diversity and Structure in Southeastern Ghana. Agroforestry Systems. 79(3): 355368. doi: https://doi.org/10.1007/s10457-010-9311-1

Camilli, F., A. Pisanelli., G. Seddaiu., A. Franca., V. Bondesan., A. Rosati., G.M. Moreno., A. Pantera., J.E. Hermansen, \& P.J.Burgess. (2018). How local Stakeholders Perceive Agroforestry Systems: an Italian Perspective, 92(4): 849-862. doi:https://doi.org/10.1007/s10457-0170127-0

Cordeiro, A.A.C., S.D. Coelho., N.C. Ramos. \& J.A.A.M, Neto. (2018). Agroforestry Systems Reduce Invasive Species Richness and Diversity in the Surroundings of Protected Areas. Agroforestry Systems 92(6): 1495-1505. doi: https://doi.org/10.1007/s10457-017-0095-4

Didu, M.S., (2001). Analisis Posisi dan Peran Lembaga serta Kebijakan dalam Proses Pembentukan Lahan Kritis. Jurnal Teknologi Lingkungan. 2(1): 93-105.doi: http://dx.doi.org/10.29122/jtl.v2i1.202

Duangta, K., Borisutdhi, Y., \& Simaraks, S. (2018). Knowledge management of pomelo production system in Northeast Thailand: A case study of the pomelo farmer group in Ban Thaen district. Forest and Society, 2(2), 162-172. doi:http://dx.doi.org/10.24259/fs.v2i2.5122

Gedgaew, C., Simaraks, S., \& Rambo, A. (2018). Factors influencing long term tomato seed production under contract farming. Forest and Society, 2(2), 150-161. doi:http://dx.doi.org/10.24259/fs.v2i2.4340

Moreno, G., S, Aviron., S, Berg., J.C. Duran., A. Franca., S. G, de Jalón., T. Hartel., J. Mirck., A. Pantera., J. H. N. Palma., J. A. Paulo., G. A. Re., F. Sanna., C. Thenail., A. Varga., V. Viaud., P. J. Burgess. (2018). Agroforestry Systems of High Nature and Cultural Value in Europe: Provision of Commercial Goods and Other Ecosystem Services. Agroforestry Systems 92(6): 877-891. https://doi.org/10.1007/s10457-017-0126-1

Hakim, L., N.R. Pamungkas., K.P. Wicaksono. \& Soemarno. (2018). Conservation Osingnese Traditional Home Garden Agroforestry in Banyuwangi, East Java, Indonesia. AGRIVITA Journal of Agricultural Science. 40(3):506-514. doi: http://doi.org/10.17503/agrivita. v40i3.1605.

Hoang, L.T., J.M. Roshetko., T.P. Huu., T. Pagella. \& P.N. Mai. (2017). Agroforestry - The Most Resilient Farming System for the Hilly Northwest of Vietnam. International Journal of Agriculture System (5)1: 1-23. doi: http://dx.doi.org/10.20956/ijas.v5i1.1166

Jalon, S.G., A. Graves.,J.H.N. Palma., A. Williams., M. Upson.P.J. Burgess. (2018). Modelling and Valuing the Environmental Impacts of Arable, Forestry and Agroforestry Systems: A Case Study. Agroforestry Systems 92(2): 1059-1073.doi:https://doi.org/10.1007/s10457-0170128-z

Knapp, K.C. \& P.A, Sadorsky. (2010). Economics of Agroforestry Production in Irrigated Agriculture. Journal of Agricultural and Resource Economics 25(1): 286-306.

Mercer, D.E., G.E. Frey. \& F.W. Cubbage. (2014). Economics of Agroforestry. In: Kant S, and J.R.R. Alavalapati (eds.). Hanbook of Forest Economics. Earthcan from Routledge. New York. 188209.

Murthy, I. K., Dutta, S., Varghese. V., Joshi. P.P., \& Kumar, P. (2016). Impact of Agroforestry Systems on Ecological and Socio-Economic Systems: A Review. Glob J Sci Front Res: H Environ Earth Sci, 16(5), 15-27.

Nuddin, A., Sinukaban, N., Murtilaksono, K., Alikodra, H.S. (2007). Analysis of institution system on 
planning and strategy of critical land on Bila Watershed management. IPB (Bogor Agricultural University).

Nuddin, A., Reskiana., Arman., S. Yusuf., Nuringsih., M. Arsyad., A. Bustan. \& A. Laapo. (2018), Designing New Strategy for Enhancing Robusta Coffee Production: An Application of Interpretative Structural Modeling. International Journal Agriculture System. 6(2): 156-163.

Nuddin, A., S. Yusuf. \& N.M.V. Sulianderi. (2015). An Alternative Model of Cocoa Production Institution: A Solution in Facing Asean Economic Community. International Journal Agriculture System. 3(2): 143-156.

Rahu, A. A., K. Hidayat., M. Ariyadi. \& L. Hakim. (2013). Ethnoecology of Kaleka: Dayak's agroforestry in Kapuas, Central Kalimantan Indonesia. Research Journal of Agricultureand Forestry Sciences, 1(8): 5-12.

Saxena, J.J.P. (1999). Hierarchy and Classification of Program Plan Elements Using Interpretative Structural Modeling. 5(6): 651-670.doi: https://doi.org/10.1007/BF01083616

Tongkaemkaew, U., Sukkul, J., Sumkhan, N., Panklang, P., Brauman, A., \& Ismail, R. (2018). Litterfall, litter decomposition, soil macrofauna, and nutrient contents in rubber monoculture and rubber-based agroforestry plantations. Forest and Society, 2(2), 138-149. doi:http://dx.doi.org/10.24259/fs.v2i2.4431

Villamor, G. B., Le, Q. B., Djanibekov, U., van Noordwijk, M., \& Vlek, P. L. (2014). Biodiversity in rubber agroforests, carbon emissions, and rural livelihoods: An agent-based model of land-use dynamics in lowland Sumatra. Environmental Modelling \& Software,61, 151-165.doi: https://doi.org/10.1016/j.envsoft.2014.07.013 